\title{
Author Correction: Tendinopathy
}

Neal L. Millar®, Karin G. Silbernagel, Kristian Thorborg, Paul D. Kirwan, Leesa M. Galatz, Geoffrey D. Abrams, George A. C. Murrell, Iain B. Mclnnes (10) and Scott A. Rodeo (1)

Correction to: Nature Reviews Disease Primers https://doi.org/10.1038/s41572-020-00234-1, published online 07 January 2021.

The original version of this article had a few incorrect citations in the Prevention section. This error has now been corrected and the correct references have been updated in the HTML and PDF versions of the article.

https://doi.org/10.1038/s41572-021-00251-8 I Published online: 03 February 2021

C Springer Nature Limited 2021 